\title{
Modelling photochemistry in alpine valleys
}

\author{
G. Brulfert, C. Chemel, E. Chaxel, and J. P. Chollet \\ Laboratory of Geophysical and industrial Fluid Flows (University J. Fourier, INP Grenoble, CNRS), BP53, 38041 Grenoble \\ cedex, France
}

Received: 1 July 2004 - Published in Atmos. Chem. Phys. Discuss.: 21 March 2005

Revised: 19 July 2005 - Accepted: 11 August 2005 - Published: 12 September 2005

\begin{abstract}
Road traffic is a serious problem in the Chamonix Valley, France: traffic, noise and above all air pollution worry the inhabitants. The big fire in the Mont-Blanc tunnel made it possible, in the framework of the POVA project (POllution in Alpine Valleys), to undertake measurement campaigns with and without heavy-vehicle traffic through the Chamonix and Maurienne valleys, towards Italy (before and after the tunnel re-opening). Modelling is one of the aspects of POVA and should make it possible to explain the processes leading to episodes of atmospheric pollution, both in summer and in winter. Atmospheric prediction model ARPS 4.5.2 (Advanced Regional Prediction System), developed at the CAPS (Center for Analysis and Prediction of Storms) of the University of Oklahoma, enables to resolve the dynamics above a complex terrain. This model is coupled to the TAPOM 1.5.2 atmospheric chemistry (Transport and Air POllution Model) code developed at the Air and Soil Pollution Laboratory of the Ecole Polytechnique Fédérale de Lausanne. The numerical codes MM5 and CHIMERE are used to compute large scale boundary forcing.
\end{abstract}

This paper focuses on modelling Chamonix valley using $300-\mathrm{m}$ grid cells to calculate the dynamics and the reactive chemistry which makes possible to accurately represent the dynamics in the Chamonix valley (slope and valley winds) and to process chemistry at fine scale. The summer 2003 intensive campaign was used to validate the model and to study chemistry. $\mathrm{NO}_{\mathrm{y}}$ according to $\mathrm{O}_{3}$ reduction demonstrates a VOC controlled regime, different from the $\mathrm{NO}_{\mathrm{x}}$ controlled regime expected and observed in the nearby city of Grenoble.

Correspondence to: G. Brulfert

(guillaume.brulfert@hmg.inpg.fr)

\section{Introduction}

Alpine valleys are sensitive to air pollution due to emission sources (traffic, industries, individual heating), morphology (narrow valley surrounded by high ridge), and local meteorology (temperature inversions and slope winds). Such situations are rarely investigated with specific research programs taking into account detailed gas atmospheric chemistry. Several studies of the influence of atmospheric dynamics over complex terrain on air quality took place with field campaigns in the Alpine area over the last two decades. The program TRANSALP (a component of EUROTRAC-TRACT) included several field campaigns, with, among others, (i) an intensive sampling campaign with high density network for ozone measurements on a $300 \times 300 \mathrm{~km}^{2}$ area (Löffler-Mang et al., 1998), (ii) an intensive sampling campaign with the follow up of the dispersion of a passive tracer released in the Rhine valley (which is about $40 \mathrm{~km}$ width on average) (Ambrosseti et al., 1998). The POLLUMET program (Lehning et al., 1996) focused on processes controlling oxidant concentrations in the Swiss Plateau. These two programs mostly dwelt with meso scale processes, and did not take into account in detail atmospheric dynamics in narrow valleys. In the same way, one of the objectives of the MAP program (http://www.map.meteoswiss.ch) was devoted to the study of the evolution of the planetary boundary layer in complex terrain at the meso scale, but no measurements were conducted in parallel on any aspect of atmospheric chemistry. The programs VOTALP I (Wotawa and Kromp-Kolb, 2000) and VOTALP II (http://www.boku.ac.at/imp/votalp/votalpII.pdf) were essentially devoted to the study of ozone production and vertical transport over the Alps. The modelling in this program (Grell et al., 2000), coupling a non hydrostatic model with a photochemistry model at a resolution of $1 \times 1 \mathrm{~km}$ for the inner domain, showed, among other, the influence of the valley wind in the advection of chemical species from the foreland to the inner valley. The authors conclude that the

(C) 2005 Author(s). This work is licensed under a Creative Commons License. 
evaluation of the pollutant budget in the valley requires a finer grid as well as a detailed emission inventory. Couach et al. (2003) present a modelling study coupling atmospheric dynamics and photochemistry (at a $2 \times 2 \mathrm{~km}$ scale) in the case of the Grenoble (France) area, which is a large glacial valley in the French Alps. This study is connected to a 3-day field campaign conducted in summer 1999, including a large array of ground and 3-D measurements dedicated to ozone and its precursors. Again, this study showed the large influence of the valley wind on the distribution of ozone concentrations. The modelled ozone concentrations were in reasonable agreement with 3-D measurements. Finally, the Air Espace Mont Blanc study (Espace Mont Blanc, 2003) was conducted by the Air Quality networks in France, Italy, and Switzerland. The field study was based on a 1 year monitoring (June 2000-May 2001) at stations around the "Massif $\mathrm{du}$ Mont Blanc", for regulated species $\left(\mathrm{SO}_{2}, \mathrm{NO}_{\mathrm{x}}, \mathrm{O}_{3}, \mathrm{PM}_{10}\right.$ and $\mathrm{PM}_{2.5}$ ).

These previous studies underlined the limitations of the models in handling detailed atmospheric dynamics in complex terrain when using only $1 \times 1 \mathrm{~km}$ resolution, while these processes are the dominant factors controlling the concentrations fields.

Following the accident under the Mont Blanc tunnel (Fig. 1) on 24 March 1999, international traffic between France and Italy was stopped through the Chamonix valley (France). The heavy-duty traffic (about 2130 trucks per day) has been diverted to the Maurienne Valley, with up to 4250 trucks per day. The campaigns were scheduled both before and after the reopening of the tunnel in order to directly investigate the impact of international heavy duty traffic on air quality. However, the reopening of the tunnel was staged in different phases from March 2002 (for personal vehicles only) until March 2003 (open to all vehicles without restriction). International traffic through the tunnel during the last two intensive observation periods of observations (IOP) had not returned to the level of the period before the accident, with only about 1840 personal vehicles and 590 trucks/day on average during the winter 2003 IOP and about 4180 personal vehicles and 910 trucks/day on average during the summer 2003 IOP.

The general topics of the POVA program (launched in 2000) are the comparative studies of air quality and the modelling of atmospheric emissions and transport in these two French alpine valleys before and after the reopening of the tunnel to heavy duty traffic to identify the sources and characterize the dispersion of pollutants. The program includes several field campaigns, associated with 3-D modelling in order to study impact of traffic and local development scenarios.

Firstly the area of interest and numerical models in use are presented together with methods to prescribe boundary conditions. Main features of the emission inventory are given. After a validation from comparison with field experiments for dynamic and chemistry, computations of photochemical indicators during a summer IPO conclude to a VOC sensitive regime.

\section{The area of interest}

The Chamonix valley is $23 \mathrm{~km}$ long, closed in its lower end by a narrow defile (the Cluse pass) and at the upper side by the Col des Montets (1464 ma.s.l.) leading to Switzerland (Fig. 1). The general orientation of the valley is globally NE-SW. With North latitude of $45.92^{\circ}$ and East longitude of $6.87^{\circ}$, the centre of the area is at approximately $200 \mathrm{~km}$ from Lyon (France), $80 \mathrm{~km}$ from Genève (Switzerland) and $100 \mathrm{~km}$ from Torino (Italy). The valley is rather narrow (1 to $2 \mathrm{~km}$ on average on the bottom part) and $5 \mathrm{~km}$ from ridge to ridge, with the valley floor at $1000 \mathrm{~m}$ a.s.l. on average, surrounded by mountains culminating with the Mont Blanc peak (4810 $\mathrm{m}$ a.s.l.). Vegetation is relatively dense with many grassland and forest areas (Fig. 2).

There are no industries or waste incinerators in the valley, and the main anthropogenic sources of emissions are vehicle traffic, residential heating (mostly with fuel and wood burning), and some agricultural activities. The resident population is about 12000 but tourism brings in many people (on average 100000 person/day in summer, and about 5 millions overnight stays per year), mainly for short term visits. There is only one main road supporting all of the traffic in and out of the valley, but secondary roads spread over all of the valley floor and on the lower slopes. During the closing of the Mont-Blanc tunnel leading to Italy, the traffic at the entrance of the valley (14400 vehicles/day on average) was mostly composed of cars (91\% of the total, including $50 \%$ diesel powered), with a low contribution of local trucks (5\%) and of buses for tourism (1\%). Natural sources of emissions are limited to the forested areas, with mainly coniferous species ( $95 \%$ of spruce, larch and fir).

\section{Model for simulation}

Because of the orography, slope winds are observed. Their thickness is around 50 to $200 \mathrm{~m}$ and depends on local orography effects. Horizontal resolution must be under $1 \mathrm{~km}$ to describe correctly meteorological and chemistry processes. A terrain following coordinate is appropriate to the vertical resolution. Non-hydrostatic models have to be used at mesoscale. The influence of regional meteorology and ozone concentration is important, overlapping models give boundary conditions.

To sum up, the modelling system for the valley itself is made of the meso-scale atmosphere model ARPS 4.5.2 and the troposphere chemistry model TAPOM 1.5.2. 


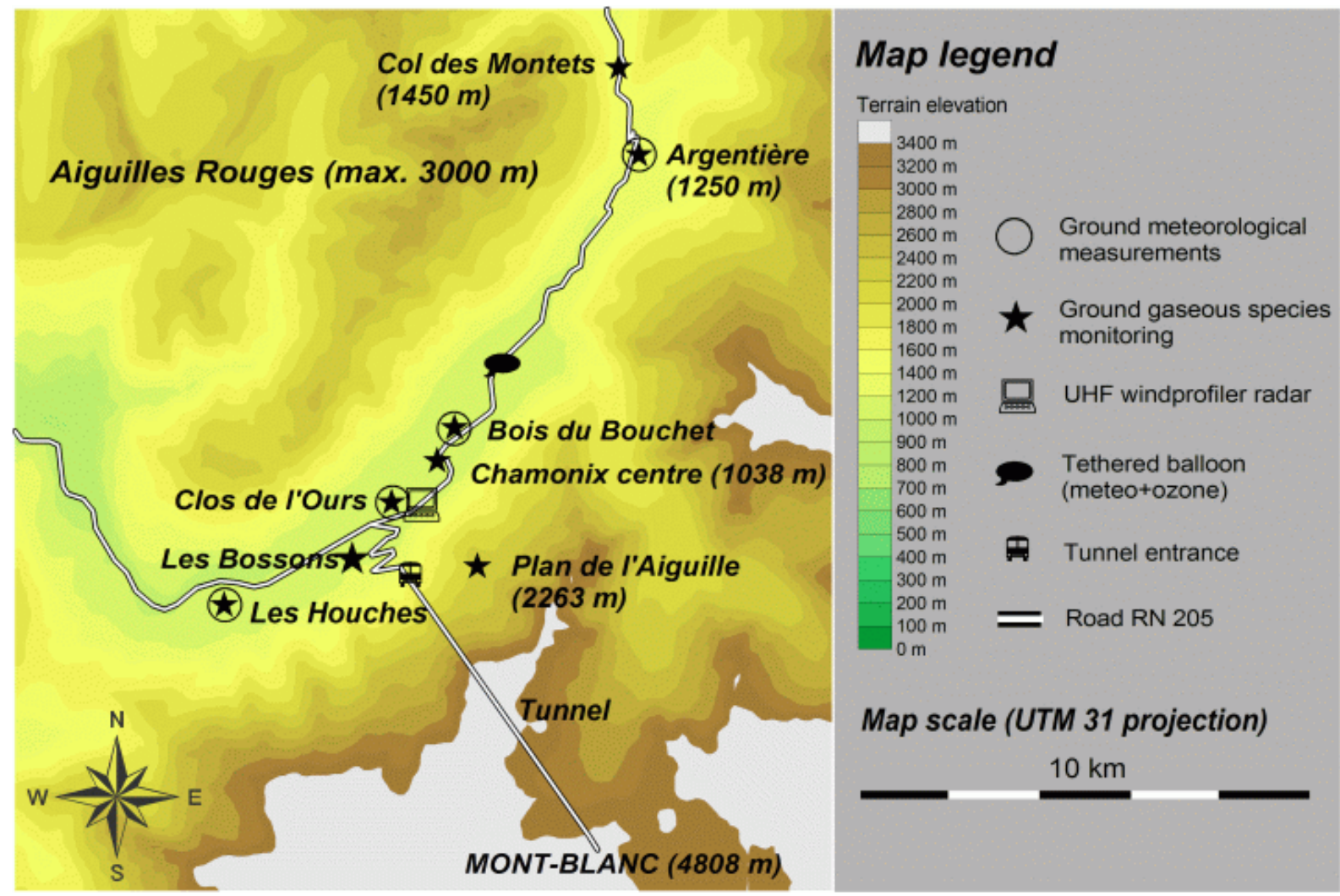

Fig. 1. Topography of Chamonix valley: main measurement sites (centre of the valley: Latitude $45.92^{\circ} \mathrm{N}$, longitude $6.87^{\circ} \mathrm{E}$ ). $\mathrm{Road}$ is the white line.

Table 1. Hierarchy of computational domains.

\begin{tabular}{llccccc}
\hline & Typical extend & $\begin{array}{c}\text { Grid nodes } \\
\mathrm{nx} \mathrm{E-W \times ny} \mathrm{N-S}\end{array}$ & $\begin{array}{c}\text { Grid size } \\
\Delta \mathrm{x}=\Delta \mathrm{y}(\mathrm{km})\end{array}$ & $\begin{array}{c}\text { Code in use } \\
\text { for dynamics }\end{array}$ & $\begin{array}{c}\text { Code in use } \\
\text { for chemistry }\end{array}$ \\
\hline Domain 1 & France & $1500 \mathrm{~km}$ & $45 \times 51$ & 27 & MM5 & CHIMERE \\
Domain 2 & Southeastern France & $650 \mathrm{~km}$ & $69 \times 63$ & 9 & MM5 & CHIMERE \\
Domain 3 & Savoie mountains & $350 \mathrm{~km}$ & $96 \times 96$ & 3 & MM5 & TAPOM \\
Domain 4 & Haute-Savoie Dept. & $50 \mathrm{~km}$ & $67 \times 71$ & 1 & ARPS & TAPOM \\
Domain 5 & Chamonix valley & $25 \mathrm{~km}$ & $93 \times 103$ & 0.3 & ARPS & TRP \\
\hline
\end{tabular}

\section{Model for atmosphere dynamics}

Large eddy simulation was used to study meso-scale flow fields in both valleys. The numerical simulations presented here have been conducted with the Advanced Regional Prediction System (ARPS), version 4.5.2 (Xue et al., 2000, 2001). Lateral boundary conditions were externally-forced from the output of larger-scale simulations performed with the Fifth-Generation Penn State/NCAR Mesoscale Model (MM5) version 3 (Grell et al., 1995). MM5 is a nonhydrostatic code which allows meteorological calculation at various scales with a two-way nesting technique. In the present study three different domains were used with MM5
(Table 1). ARPS is used at finer grids because MM5 was observed not to be accurate enough at resolution less than $1 \mathrm{~km}$ (Chaxel et al., 2004). For the Chamonix valley modelling with ARPS, two grid nesting levels were used as shown in Table 1. A geographical description of domains is available in Fig. 3.

\subsection{Model for atmosphere chemistry}

ARPS is coupled off-line with the TAPOM 1.5.2 code of atmospheric chemistry (Transport and Air POllution Model) developed at the LPAS of the EPFLausanne (Clappier, 1998; Gong and Cho, 1993). 300-m grid cells to calculate 


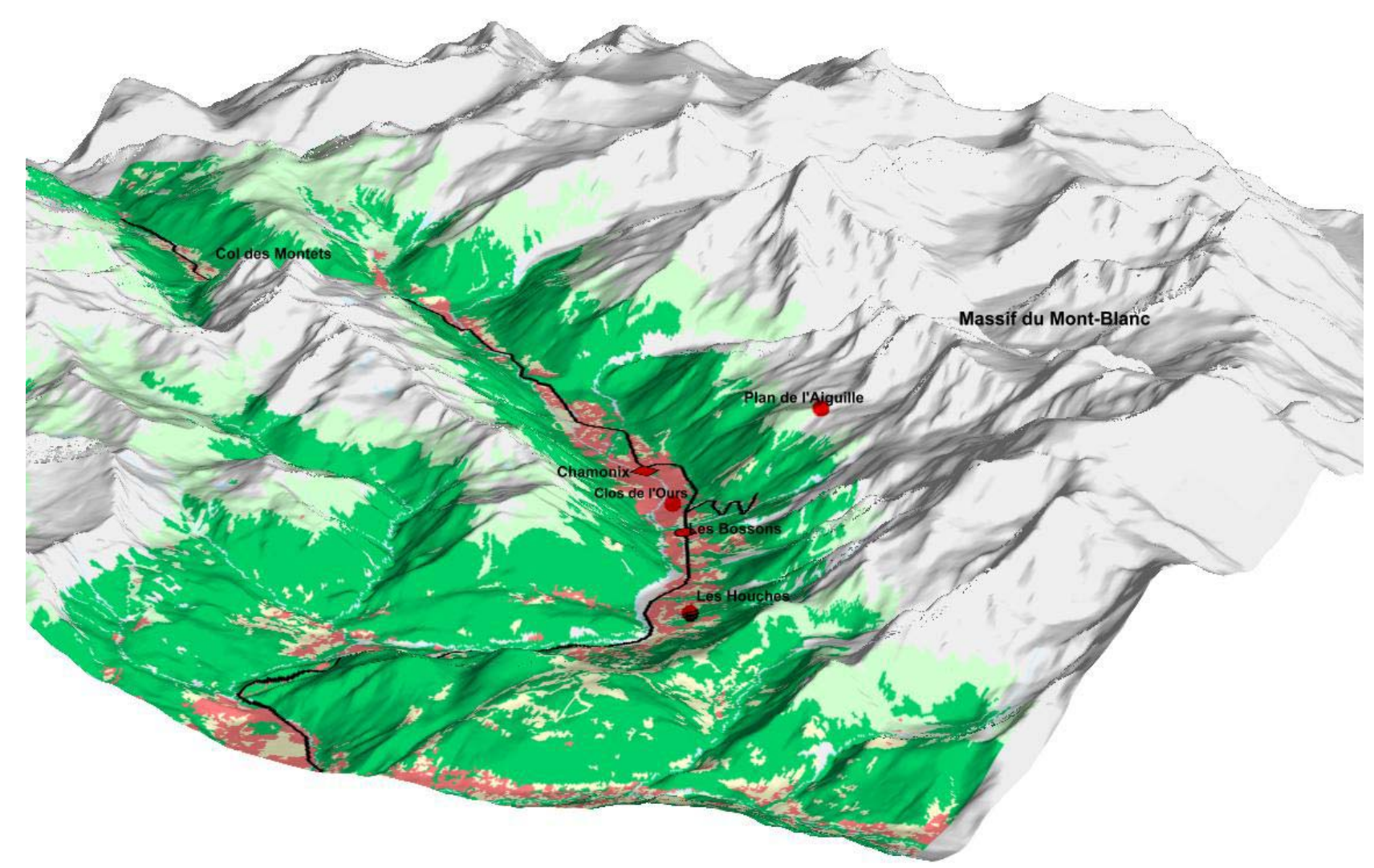

Fig. 2. Landuse of Chamonix valley in summer. Red is infrastructure, yellow is grassland, dark green is forest, pale green is high altitude vegetation, white-grey is rock and snow, the dark line is the main road.
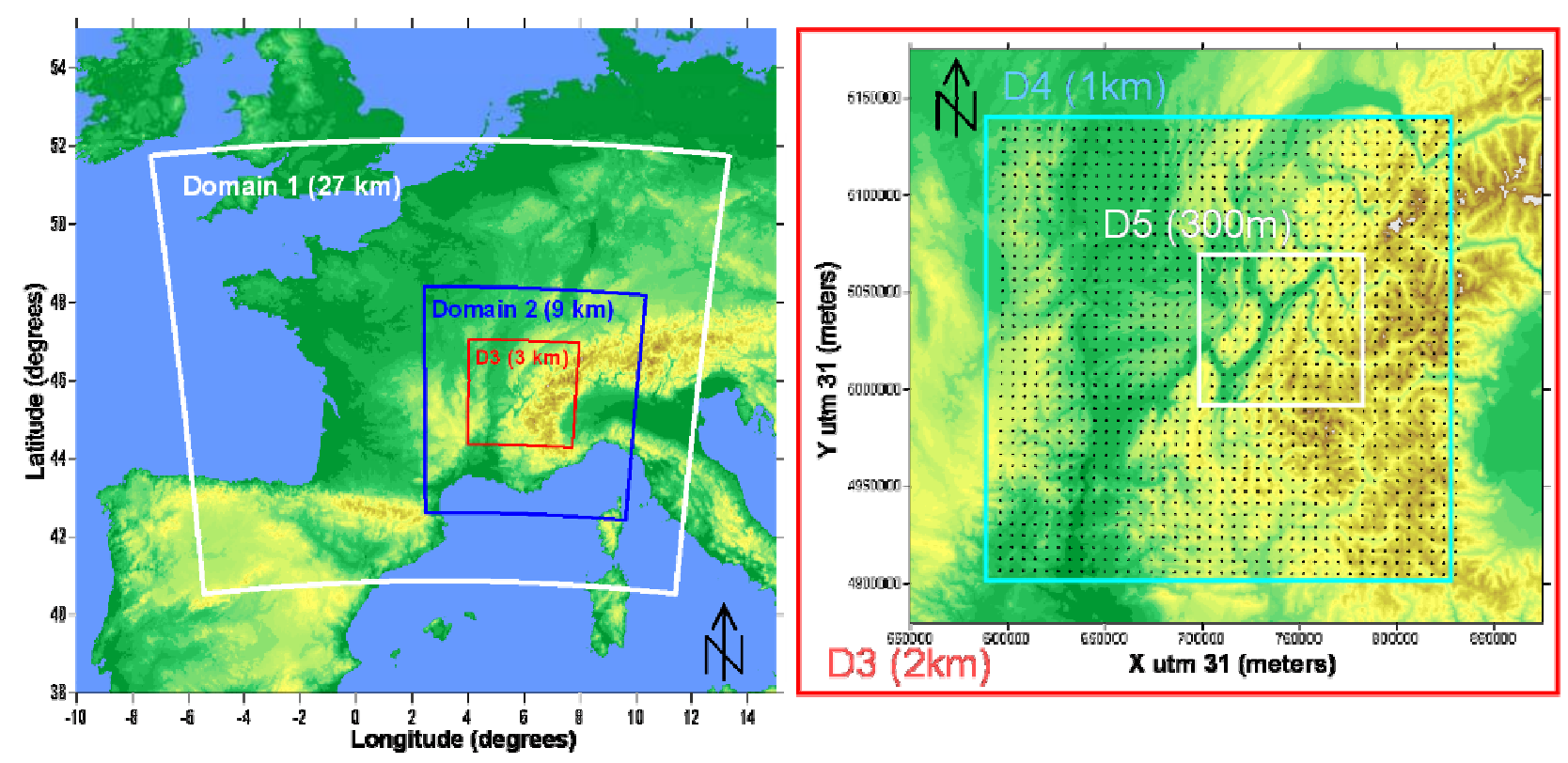

Fig. 3. Geographical description of MM5 (D1, D2, D3) domains over Europe and ARPS (D4, D5) domains over Haute-Savoie department. 

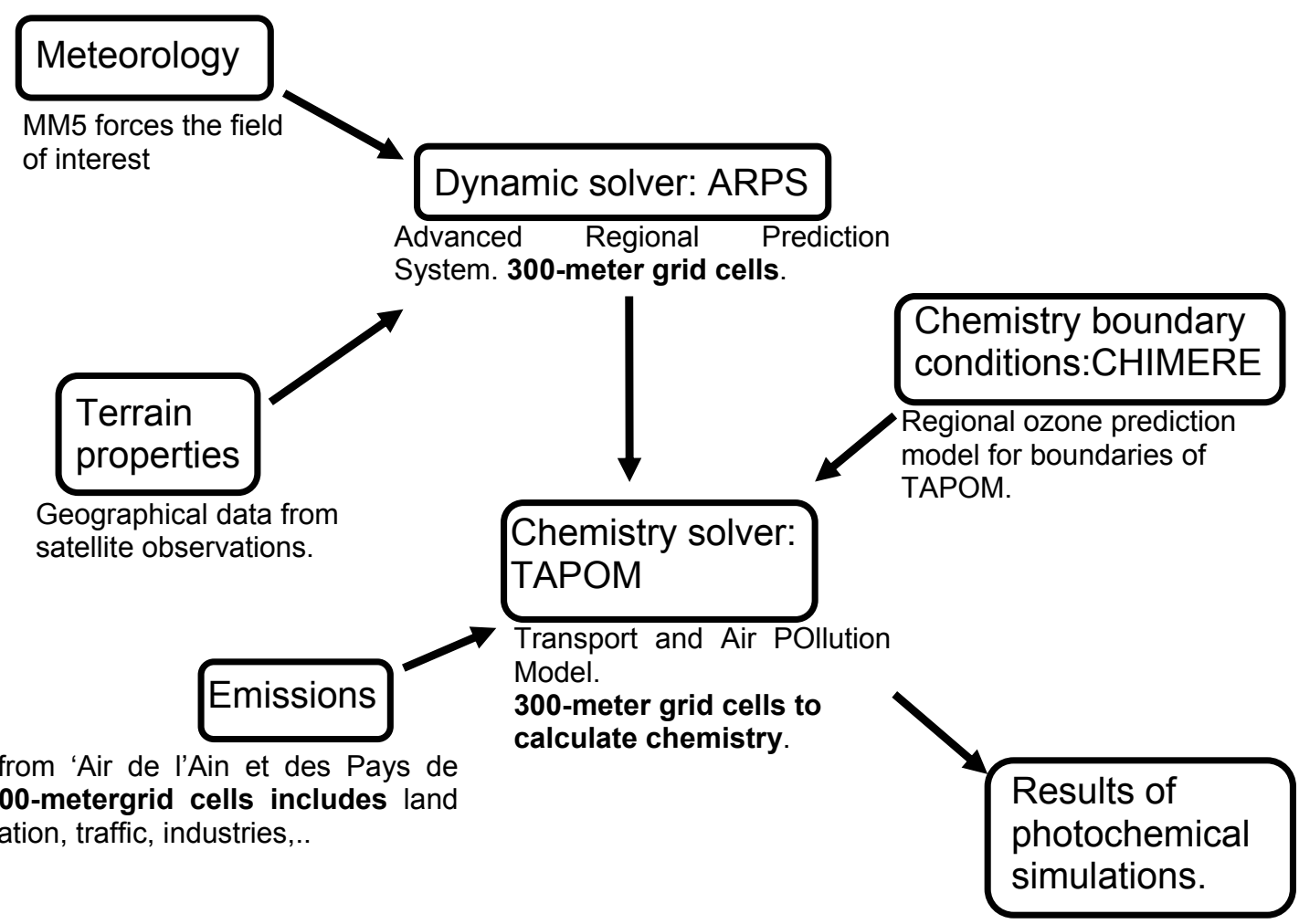

Fig. 4. Description of the modelling system for photochemical simulations.

dynamics and reactive chemistry make possible to accurately represent dynamics in the valley (slope winds) (Anquetin et al., 1999) and to process chemistry at fine scale.

TAPOM is a three dimensional eulerian model with terrain following mesh using the finite volume discretisation. It includes modules for transport, gaseous and aerosols chemistry, dry deposition and solar radiation. It takes into account the extinction of solar radiation by gases and aerosols in the gaseous chemistry calculation. Chemistry and pollutant transport are not expected to significantly change atmosphere radiative properties. Hence chemistry is considered not to modify dynamics which allows off-line coupling: meteorological data computed from ARPS are passed on to TAPOM every 20 min with linearly interpolating data in between. A full description of the ARPS-TAPOM coupling is given in Brulfert (2004). TAPOM uses the Regional Atmospheric Chemistry Modelling (RACM) scheme (Stockwell et al., 1997). RACM is a completely revised version of RADM2. The mechanism includes 17 stable inorganic species, four inorganic intermediates, 32 stable organic species (four of these are primarily of biogenic origin) and 24 organic intermediates, in 237 reactions. In RACM, the VOCs are aggregated into 16 anthropogenic and three biogenic model species. The grouping of chemical organic species into the RACM model species is based on the magnitudes of the emissions rates, similarities in functional groups and the compound's reactivity toward $\mathrm{OH}$ (Middleton et al., 1990). RACM was compared with other photochemical mechanisms and it gives very good results for $\mathrm{O}_{3}$ with regards to the percentage of deviation of individual mechanisms from average values (Jimenez et al., 2003).

For the boundary conditions, CHIMERE, a regional ozone prediction model, from the Institut Pierre Simon Laplace, gives concentrations of chemical species at five altitude levels (Schmidt et al., 2001) using its recent multi-scale nested version.. Then, CHIMERE is used at a space resolution of $27 \mathrm{~km}$ and $6 \mathrm{~km}$ to give chemical species initialisation and boundaries. Chemical concentrations calculated on a large scale domain are used at the boundaries of a smaller one. Then, we can have a very good description of the temporal variation of the background concentrations of ozone and of other secondary species. It is possible to use CHIMERE data for TAPOM because the chemical mechanism (respectively MELCHIOR and RACM) are close on to the other.

The whole methodology of modelling system to obtain photochemical simulations is described in Fig. 4.

\section{Emission inventory}

The emission inventory is based on the CORINAIR methodology and SNAPS's codes, with a $100 \times 100 \mathrm{~m}$ grid and includes information (land use, population, traffic, 
Table 2. Emission inventory for 1998 in the area of interest (t year ${ }^{-1}$ ).

\begin{tabular}{|c|c|c|c|c|c|}
\hline & $\mathrm{CO}$ & NMVOC & $\mathrm{NO}_{\mathrm{x}}$ & $\mathrm{SO}_{2}$ & PM \\
\hline Yearly emissions $\left(\mathrm{t}_{\text {year }}{ }^{-1}\right)$ & 827 & 535 & 551 & 194 & 79 \\
\hline Biogenic sources ( $\%$ of the year) & $0 \%$ & $51 \%$ & $2 \%$ & $0 \%$ & $0 \%$ \\
\hline Commercial and residential plants ( $\%$ of the year) & $30 \%$ & $3 \%$ & $10 \%$ & $61 \%$ & $91 \%$ \\
\hline Road transport (\% of the year) & $70 \%$ & $19 \%$ & $88 \%$ & $39 \%$ & $9 \%$ \\
\hline Domestic solvent ( $\%$ of the year) & $0 \%$ & $15 \%$ & $0 \%$ & $0 \%$ & $0 \%$ \\
\hline Gasoline distribution (\% of the year) & $0 \%$ & $12 \%$ & $0 \%$ & $0 \%$ & $0 \%$ \\
\hline
\end{tabular}

Table 3. Classes of the emission inventory.

\begin{tabular}{lll}
\hline Traffic sources & $\begin{array}{l}\text { Anthropogenic } \\
\text { sources }\end{array}$ & $\begin{array}{l}\text { Biogenic } \\
\text { sources }\end{array}$ \\
\hline $\begin{array}{l}\text { Heavy vehicles } \\
\text { Utilitarian vehicles on motorway }\end{array}$ & $\begin{array}{l}\text { Commercial boiler } \\
\text { Residential boiler }\end{array}$ & $\begin{array}{l}\text { Forest } \\
\text { Grassland }\end{array}$ \\
Utilitarian vehicles on road & Domestic solvent & \\
Cars & Gas station & \\
Cars in city & & \\
Aerial traffic & & \\
\hline
\end{tabular}

industries...) gathered from administrations and field investigations. The area covers $695 \mathrm{~km}^{2}$. The emission inventory is space and time-resolved and includes the emissions of $\mathrm{NO}_{\mathrm{x}}$, $\mathrm{CO}, \mathrm{CH}_{4}, \mathrm{SO}_{2}$ and non methane volatile organic compounds (NMVOC). As expected, the result which includes both biogenic and anthropogenic sources, shows large emissions of pollutants due mainly to the presence of road transport and plants (Table 2).

These emissions are lumped into 19 classes of VOC as required by the Regional Atmospheric Chemistry Mechanism (RACM) (Stockwell et al., 1997).

Emission classes are given in the Table 3. The emission inventory takes into account roads and access ramps to the tunnel adjusting emissions to the slope of the road. A specific feature of emission is the significant contribution of heavy vehicles (>32 tons). The emissions are distributed at the hourly level by taking account of the season and the day of the week. Further details on this emission inventory are given (Brulfert et al., 2005).

\section{Validation}

The simulations presented here take a full account of the real meteorology of the week of computation during the summer POVA IPO (5 July 2003 to 11 July 2003).
6.1 High-resolution meteorological simulation: comparison with surface and wind profiler data

The redistribution of pollutants and therefore the ozone production is very dependent on meteorological conditions. The observed meteorological situation during the 7 days of intensive period of observation (IPO) is summarized in Table 4. A north westerly wind with sun prevailed. In this complex mountainous area, wind balance and slope winds are important for the transport of chemical species.

To validate the simulated meteorological fields, we compare the model results to surface observations (Fig. 5). Temperature at sites "Les Houches", "Chamonix" and "Argentière" shows reasonable agreement for the minimum and maximum, respectively at 01:00 and 13:00 TU. A slight discrepancy at minimal value may be attributed to the difficulties in accurately modelling cooling of lower layer and humidity content of soil canopy at night. One of the difficulties was to parameter the humidity and the soil temperature without measurements. Furthermore, the real soil of these valleys is heterogeneously distributed in small parcels strongly differing one from the other: grassland, rocks, forests, ice.

Results in Fig. 5 are given from the very beginning of the computation, significant discrepancies on the first day are then to be attributed to the spin-up from initial conditions. Discrepancies on 9 July are due to a stormy day (Table 4) since ARPS was run in fine weather conditions without activating nebulosity and detailed micro physics. Maxima values of temperature are often overestimated partly due to inaccuracies in detailed soil description, partly because of the shift from computed value at the centre of the first mesh to ground level.

Wind force at site "Clos de l'ours" corresponds to measurement with maximum at 13:00 TU, nocturnal cycle is present. The computed wind velocity at the station "Bois du Bouchet" is more important than the real velocity because of a local effect with this station: trees are very close and slow down wind at ground level especially when flowing down valley.

Shifts in wind direction occur at the right times at sites "Bois du Bouchet", "Argentière" and "Clos de l'ours" at 08:00 and 20:00 TU. Discrepancies in wind direction at the 
Les Houches monitoring station

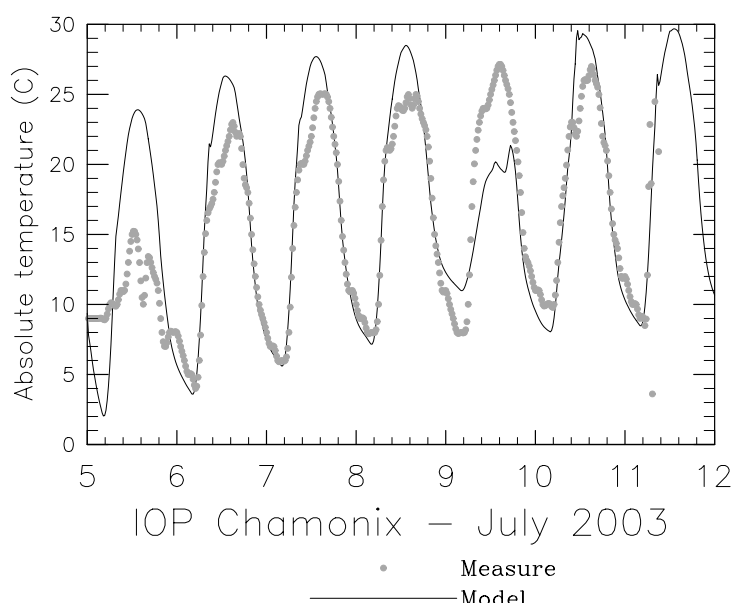

Argentiere monitoring station

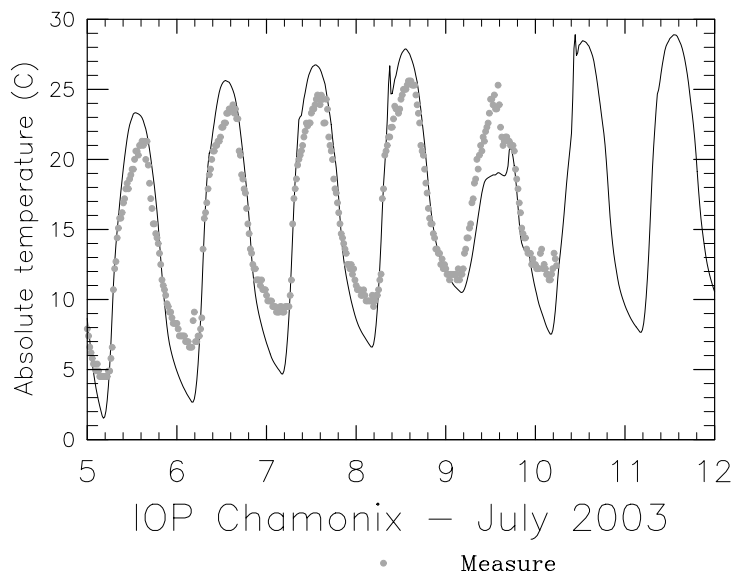

Argentiere monitoring station

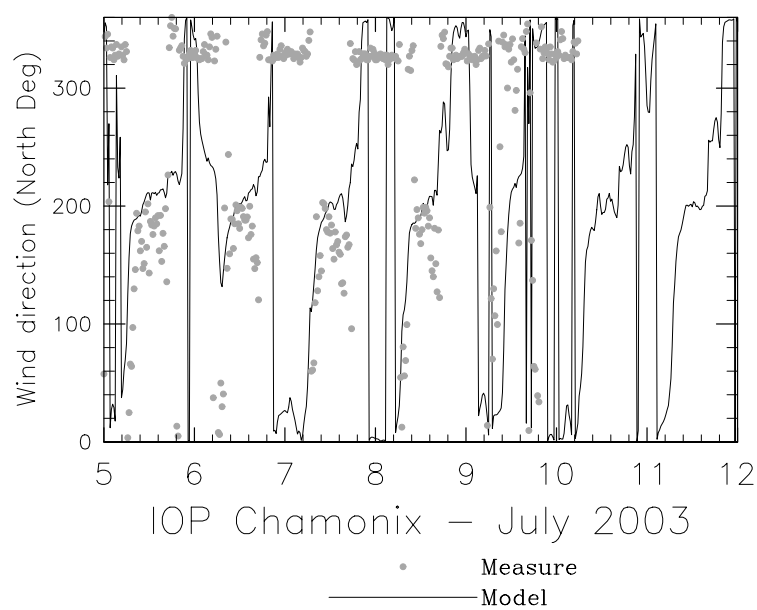

Chamonix monitoring station

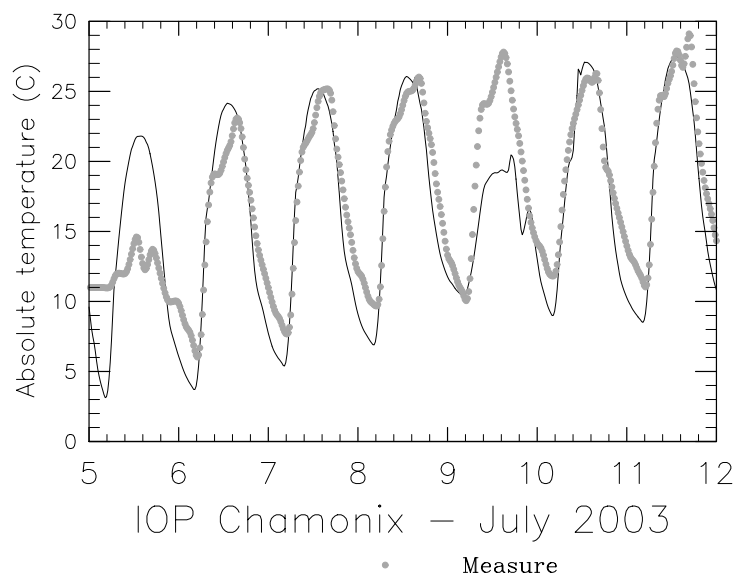

Bois du Bouchet monitoring station

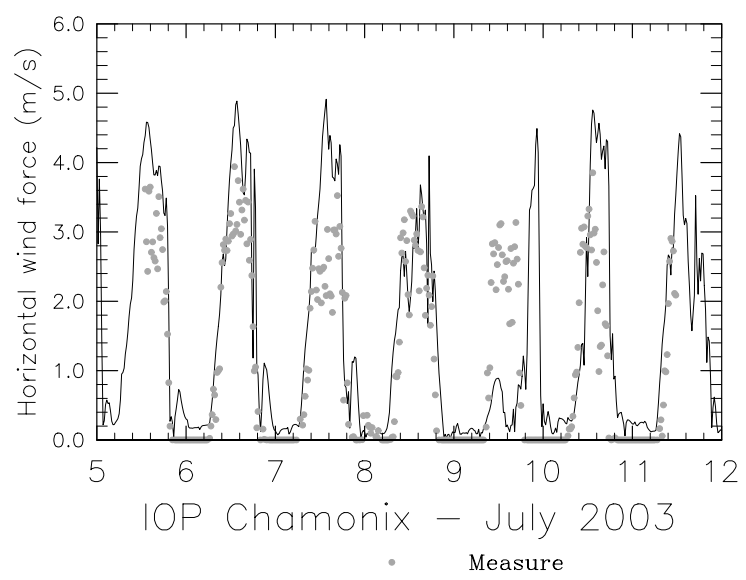

Bois du Bouchet monitoring station

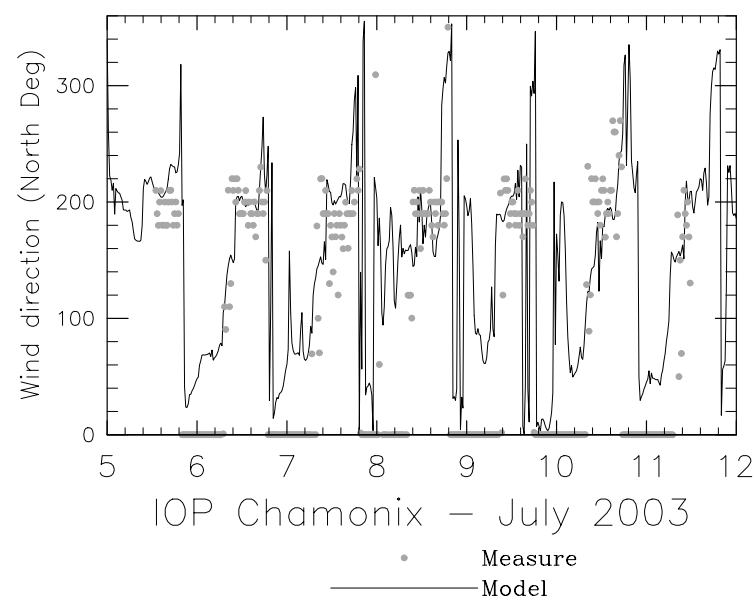

Fig. 5. Meteorological monitoring station compared to results from the simulation. Measure is represented by points, model by line. 
Table 4. IOP 2003 meteorology from 5 July to 11 July.

\begin{tabular}{|c|c|c|c|c|c|c|c|}
\hline & 5 July 03 & 6 July 03 & 7 July 03 & 8 July 03 & 9 July 03 & 10 July 03 & 11 July 03 \\
\hline $\begin{array}{l}\text { Description of } \\
\text { the situation }\end{array}$ & & & & & & & \\
\hline $\begin{array}{l}\operatorname{Tmin}\left({ }^{\circ} \mathrm{C}\right) \\
\text { Tmax }\left({ }^{\circ} \mathrm{C}\right) \\
\text { Isotherm } 00^{\circ} \mathrm{C} \\
\text { Wind description } \\
\text { at } 4500 \mathrm{~m} \text { asl }\end{array}$ & $\begin{array}{c}4 \\
22 \\
3700 \mathrm{~m} \\
\mathrm{NW} \\
2.5 \mathrm{~m} / \mathrm{s}\end{array}$ & $\begin{array}{c}5 \\
24 \\
3850 \mathrm{~m} \\
\mathrm{NW} \\
4 \mathrm{~m} / \mathrm{s} \\
\end{array}$ & $\begin{array}{c}6.5 \\
25 \\
3700 \mathrm{~m} \\
\mathrm{~W} \\
4 \mathrm{~m} / \mathrm{s} \\
\end{array}$ & $\begin{array}{c}7 \\
26 \\
4200 \mathrm{~m} \\
(<1 \mathrm{~m} / \mathrm{s}) \text { Not } \\
\text { significant } \\
\end{array}$ & $\begin{array}{c}8.5 \\
26 \\
4000 \mathrm{~m} \\
(<1 \mathrm{~m} / \mathrm{s}) \text { Not } \\
\text { significant }\end{array}$ & $\begin{array}{c}8 \\
28 \\
4100 \mathrm{~m} \\
\mathrm{~N} \text { to } \mathrm{NW} \\
5.5 \mathrm{~m} / \mathrm{s} \\
\end{array}$ & $\begin{array}{c}8 \\
27 \\
4000 \mathrm{~m} \\
\mathrm{NW} \\
7 \mathrm{~m} / \mathrm{s} \\
\end{array}$ \\
\hline
\end{tabular}

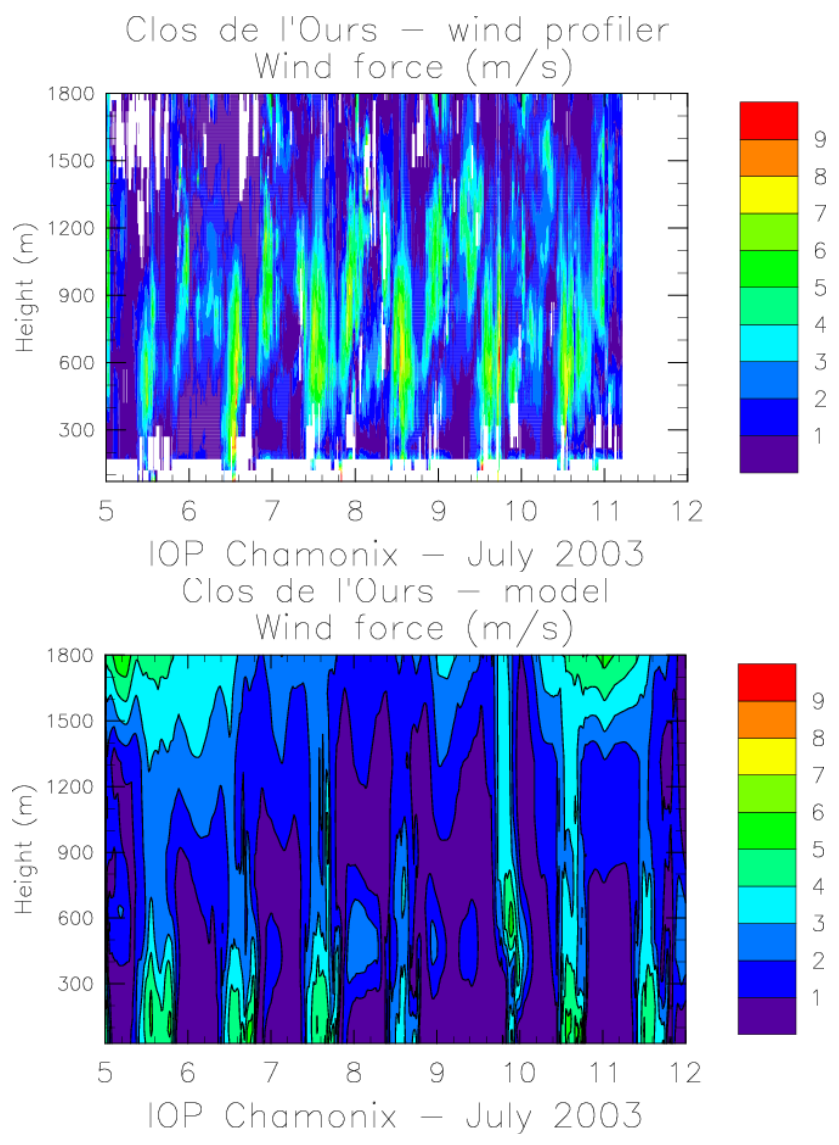

Fig. 6a. Wind force from the wind profiler (top) compared to results (bottom) from the computation.

beginning and end of each shift in Fig. 5 are non significant since corresponding to weak and therefore inaccurately measured wind.

Profiler data are in good agreement with values from the model (Figs. 6a and b): wind reversal starts and stops at the same time. The altitude of the synoptic wind is well represented. Model results taken into account come from the first layer above the topography. ARPS works with a terrain fol-

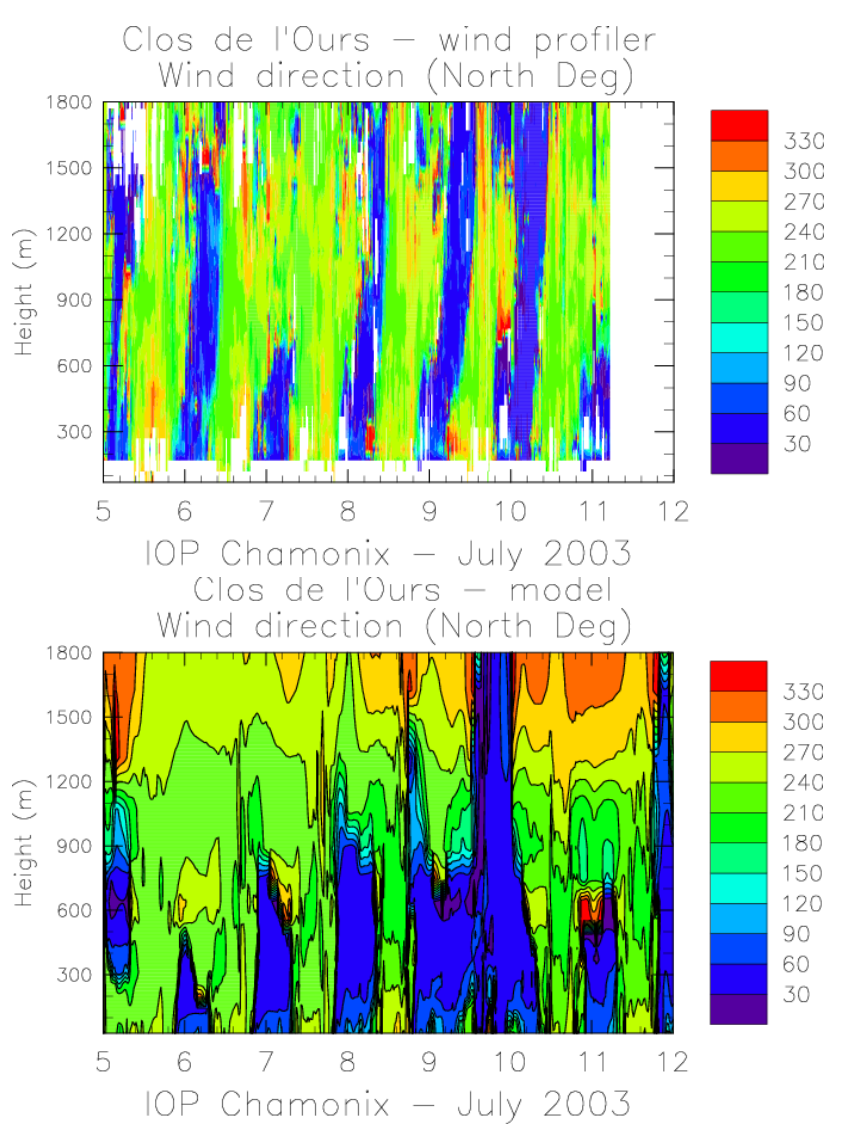

Fig. 6b. Wind direction from the wind profiler (top) compared to results from the computation (bottom).

lowing coordinate. As above mentioned, wind direction has not to be considered for weak (e.g. less than $1 \mathrm{~m} \mathrm{~s}^{-1}$ ) wind.

The boundary layer thickness can be estimated from wind profiler data. It is well simulated all along the day, except on 9 July because of stormy instable weather. Further discussion about measurements and layer thickness assessment is given in (Chemel and Chollet., 2005 ${ }^{1}$ ).

\footnotetext{
${ }^{1}$ Chemel, C., Chollet, J. P.: Observations of the daytime atmospheric boundary layer in deep alpine valleys,Boundary-Layer
} 
Finally, we can say that the simulated meteorological fields are very realistic: temperature does not show significant bias. The evolution of the thickness of the inversion layer is well simulated. Wind direction and forces are well reproduced with wind reversal observed at the same times in the model and from measurements. Therefore, meteorological fields may be viewed as realistic enough to drive transport and mixing of chemical species.

6.2 High-resolution chemistry simulation: comparison with surface data

Concentrations of pollutants in the valley (such as $\mathrm{O}_{3}$ or $\mathrm{NO}_{2}$ ) are rather low at least when compared with large cities: values peak at $75 \mathrm{ppb}$ for $\mathrm{O}_{3}$ and $40 \mathrm{ppb}$ for $\mathrm{NO}_{2}$ compared to $100 \mathrm{ppb}$ for $\mathrm{O}_{3}$ and $50 \mathrm{ppb}$ for $\mathrm{NO}_{2}$ in nearby city of Lyon or Grenoble. To validate the simulated chemical fields, model results and surface observations are compared during the summer 2003 IPO. Model results taken into account come from the first layer above the topography. TAPOM works with a terrain following coordinate.

Ozone from the observation and from the model is in good agreement in both urban and rural stations (Fig. 7). Both spatial and temporal variability of the simulated ozone concentrations correspond reasonably well to the measured values. Figure 9 shows the correlations between the measured and simulated ozone concentrations for all the IPO days except for the stormy day (9 July, 2003). Values of correlation coefficients are significantly high with $0.73<\mathrm{R}^{2}<0.76$. The correlation coefficient $R$ between results from the model (f) and measurements ( $r$ ) is defined as:

$$
R=\frac{\frac{1}{N} \sum_{n=1}^{N}\left(f_{n}-\bar{f}\right)\left(r_{n}-\bar{r}\right)}{\sigma_{f} \sigma_{r}},
$$

where $\bar{f}$ and $\bar{r}$ are the mean values and $\sigma_{f}$ and $\sigma_{r}$ are the standard deviations of $\mathrm{f}$ and $\mathrm{r}$, respectively.

These results can be compared to the same correlations in Grenoble during a high ozone episode with $R^{2}=0.64$ for urban station and $\mathrm{R}^{2}=0.42$ for suburban stations (Couach et al., 2004).

The model significantly underestimates $\mathrm{O}_{3}$ at night in "Les Bossons". It may be attributed to the proximity of the motorway $(120 \mathrm{~m})$ and the tunnel entrance $(240 \mathrm{~m})$. Because of poor mixing at night, $\mathrm{NO}_{\mathrm{x}}$ may be overestimated by the model. The overestimation observed at station "Argentière" is due to $\mathrm{NO}_{\mathrm{x}}$ emissions which are presumably underestimated in this rural part of the valley because of a lack of any local traffic record.

Background stations ("Col des Montets" and "Plan de l'aiguille") are directly under regional influence. The amplitude of the variation of ozone concentrations are low, it does not make sense to give correlation coefficient. The relative

Meteorology, in review, 2005. mean error on ozone concentration all along the IPO (with the stormy day) is $14 \%$ at the site "Plan de l'aiguille" and 6\% for the site "Col des Montets" (respectively 12 and 3\% without the first day spin up).

It is possible to observe a more important effect of local sources in the south part of the valley: amplitude of ozone concentration is more important for "Chamonix centre", "Clos de l'ours", "Bossons" and "Bois du Bouchet". There is a titration of ozone by NO emissions. In the north part of the valley, amplitude of concentration is less important, with values of background at site "Argentière" and " $\mathrm{Col}$ des Montets". Road traffic is less important there.

The influence of regional ozone in the valley is preponderant. If we correlate daily maximum of ozone concentration at every site with the concentration of background stations at the same hour, high values of coefficients of correlation are obtained $\left(\mathrm{R}^{2}=0.87\right.$ for "Col des Montets" station and $\mathrm{R}^{2}=0.79$ for "Plan de l'aiguille" station) as shown with Fig. 10.

Ratio of regional $\mathrm{O}_{3}$ concentration to urban stations daily maximum (at the hour of the maximum) gives important information about regional influence of $\mathrm{O}_{3}$. High values $(\approx 1)$ are associated with regional preponderance and low values with local influence. Here, we have important values (ratio $>0.96$ when compared with the two background stations).

In order to illustrate how ozone concentration distributes in space according to wind regime, Fig. 11 shows the wind and ozone concentration fields, at first grid level, at 12:00 and 21:00, corresponding to daytime and night time regimes, respectively. At 12:00 the ozone concentration at the bottom of the valley is driven by regional level owing to mixing through thermal convection. At 21:00, ozone level decays along the main road and around Chamonix because of titration by traffic emissions. The upper part of the valley is less affected by $\mathrm{NO}_{\mathrm{x}}$ emission (there is no titration of ozone).

$\mathrm{NO}_{2}$ concentration at sites "Bossons", "Clos de l'Ours" and "Argentières" leads to the same conclusion as for ozone (Fig. 8): only the south part of the valley is really affected by traffic emissions. Concentrations of $\mathrm{NO}_{2}$ decrease when going to the north of the valley. Dilution of pollutants by wind transport is weak: important concentrations are observed only close to the sources. $\mathrm{NO}_{2}$ correlations are satisfactory but an improvement of the emission inventory for city and secondary traffic should improve results.

Nitric acid levels are low but well simulated (Fig. 8). CO concentration (Fig. 8) measured and simulated are more than 15 times inferior to the air quality norm $(8591 \mathrm{ppb}$, on $8 \mathrm{~h})$.

\section{Photochemical indicators to distinguish ozone pro- duction regime}

Narrow valleys in mountainous environment are very specific areas when it comes to air quality. Emission sources 

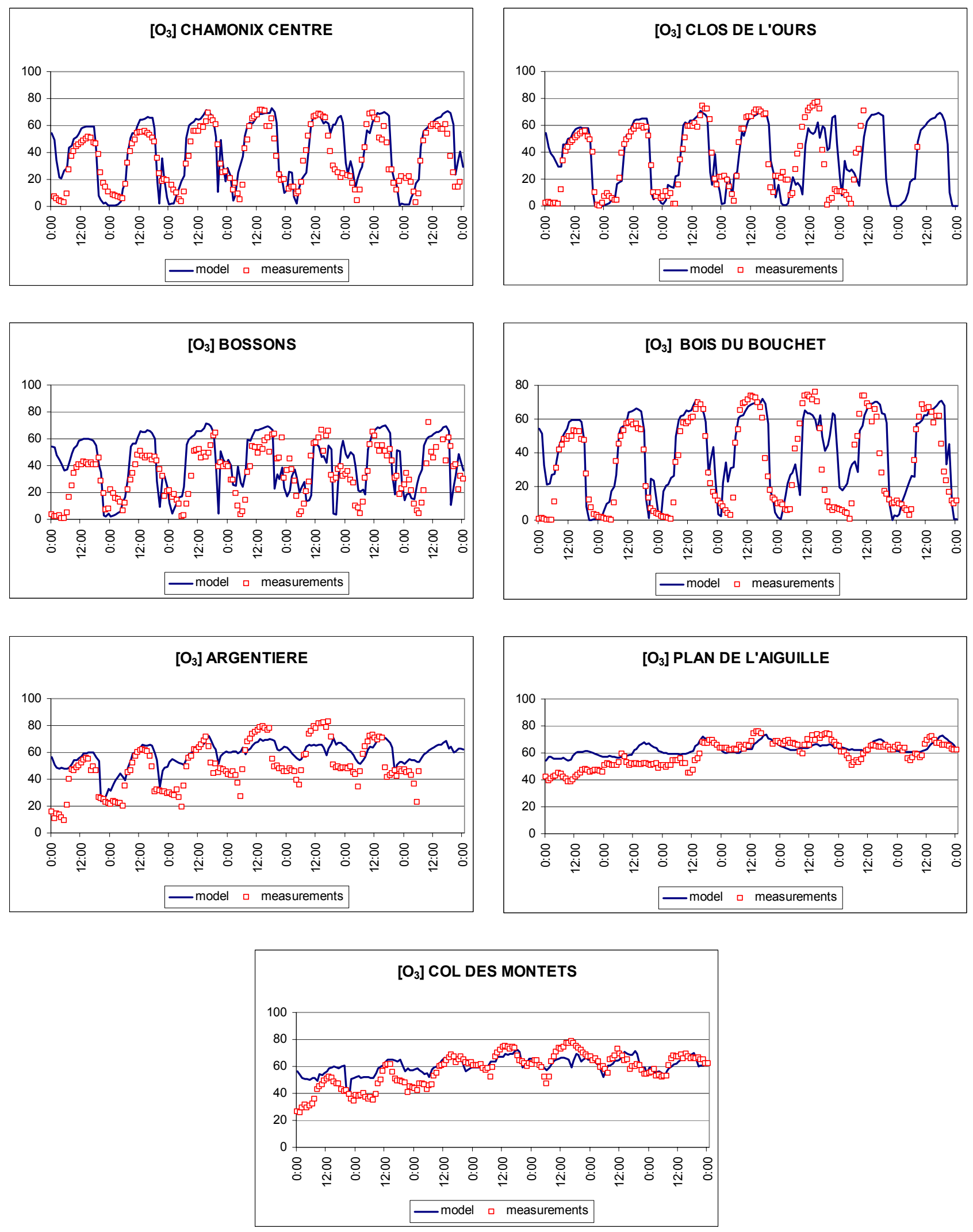

Fig. 7. Concentrations of $\mathrm{O}_{3}$ at different ground stations compared to results of the model (ppbV). Time on figures is universal time from 5 July to 11 July 2003 (IOP period). 

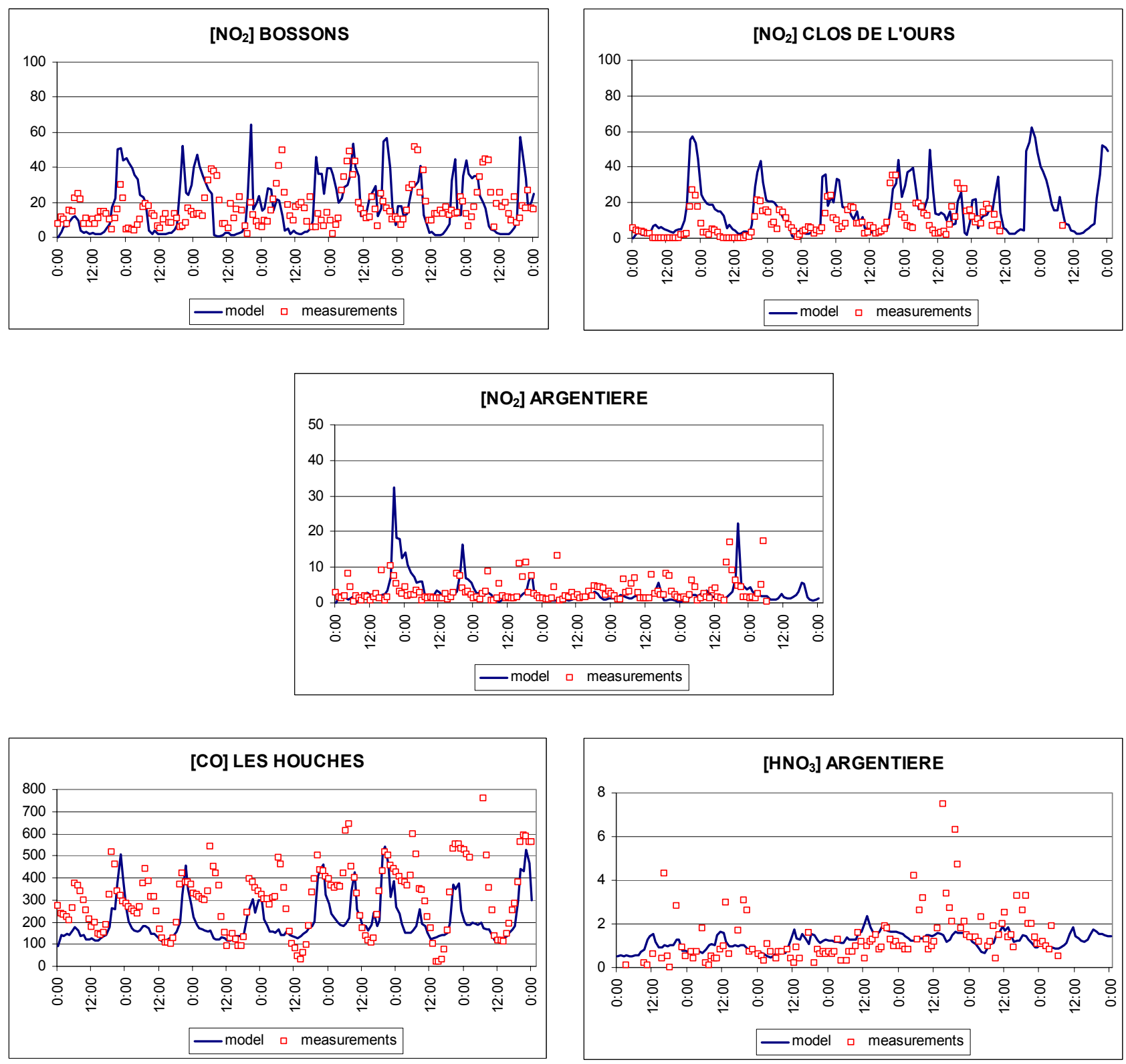

Fig. 8. Concentrations of $\mathrm{CO}, \mathrm{NO}_{2}, \mathrm{HNO}_{3}$ at different ground stations compared to results of the model (ppbV). Time on figures is universal time from 5 July to 11 July 2003 (IOP period).

are generally concentrated close to the valley floor, and very often include industries and transport infrastructures. For developing ozone abatement strategies in a specific area, it is important to know whether the ozone production is limited by $\mathrm{VOC}$ or $\mathrm{NO}_{\mathrm{x}}$. In order to understand the impact of the emissions sources on ozone production regime, three simulations are performed. All of them are based on meteorology and emission inventory of 6 July, 2003. Run B is the simulation of 7 July. Run $\mathrm{N}$ corresponds to an arbitrary reduction in $\mathrm{NO}_{\mathrm{x}}$ emissions of $50 \%$. Run $\mathrm{V}$ is obtained with an arbitrary reduction in VOC emissions of 50\%. The three runs are described in Table 5.
This reduction of $50 \%$ of $\mathrm{NO}_{\mathrm{x}}$ can be compared with the traffic reduction between 1998 and 2001. The 50\% decrease in $\mathrm{NO}_{\mathrm{x}}$ roughly corresponds to the reduction observed between 1998 (with full transit traffic through the valley) and 2001 (no transit traffic): the main source of $\mathrm{NO}_{\mathrm{x}}$ in summer is traffic (Table 2). But a $10 \%$ VOC reduction only is associated to this traffic reduction.

7 July, 2003 is representative of a summer sunny day with mean pollution level. Photochemical indicators are considered in order to distinguishing $\mathrm{NO}_{\mathrm{x}}$ limited and VOC limited ozone formation. 

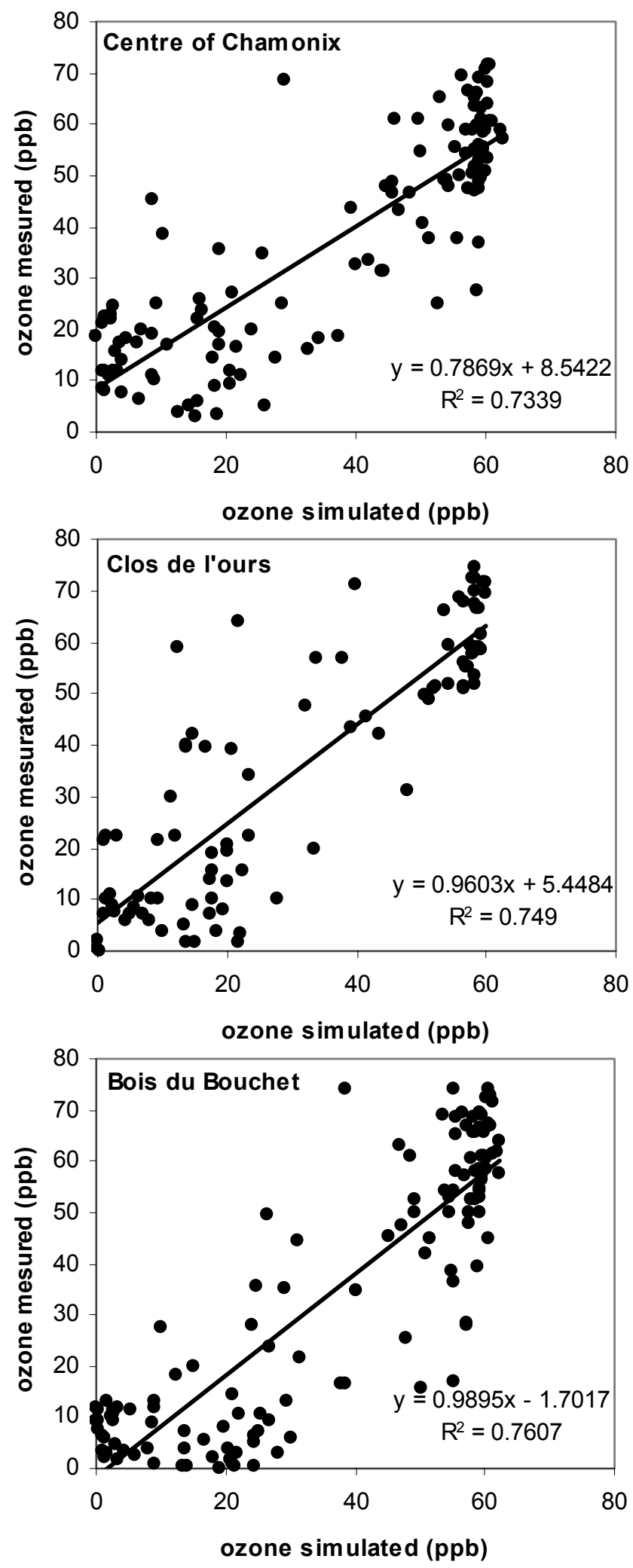

Fig. 9. Comparison between measured and simulated ozone in three sites for the IPO.

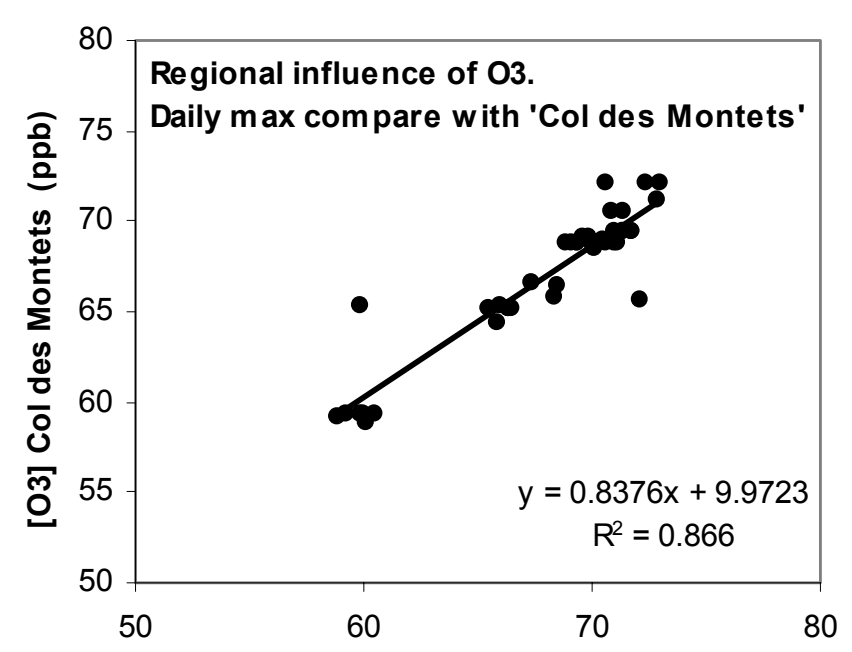

Daily max of [03] (ppb)

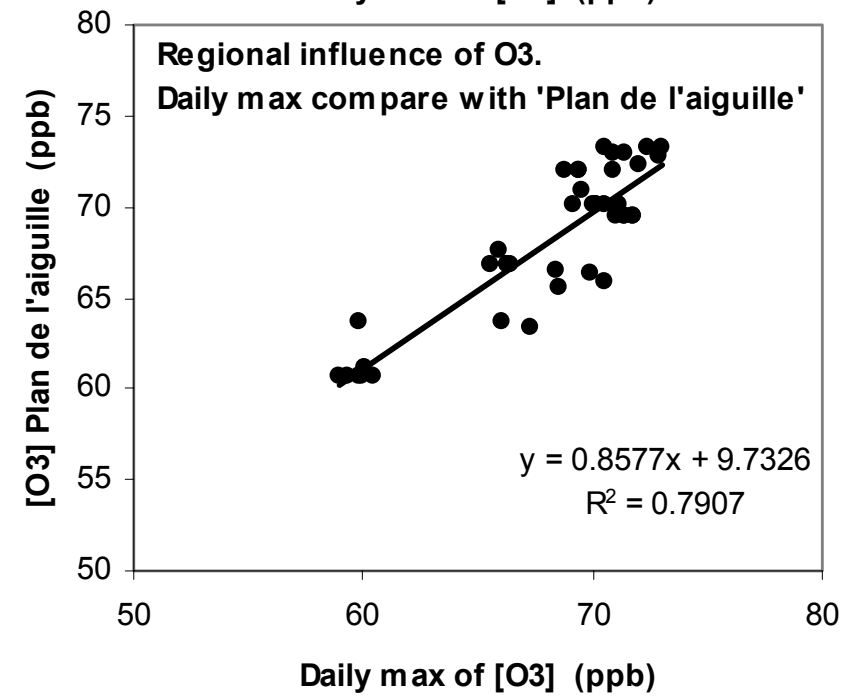

Fig. 10. Comparison between daily maximum of $\mathrm{O}_{3}(6$ sites $)$ and concentration of $\mathrm{O}_{3}$ at the same hour for background stations during the IPO.

The indicators under consideration is $\mathrm{NO}_{\mathrm{y}}$ $\left(\mathrm{NO}_{\mathrm{y}}=\mathrm{NO}_{\mathrm{x}}+\mathrm{HNO}_{3}+\mathrm{PAN}\right)$ (Milford et al., 1994). The rationale for $\mathrm{NO}_{\mathrm{y}}$ as an indicator is based in part on the impact of stagnant meteorology on $\mathrm{NO}_{\mathrm{x}}-\mathrm{VOC}$ sensitivity. Stagnant meteorology and associated high $\mathrm{NO}_{\mathrm{x}}, \mathrm{VOC}$, and $\mathrm{NO}_{\mathrm{y}}$ cause an increase in the photochemical life times of $\mathrm{NO}_{\mathrm{x}}$ and VOC, with the result that an aging urban plume remains in the VOC-sensitive regime for a longer period of time. With more vigorous meteorological dispersion and lower $\mathrm{NO}_{\mathrm{x}}, \mathrm{VOC}$ and $\mathrm{NO}_{\mathrm{y}}$ an aging urban plume would rapidly become $\mathrm{NO}_{\mathrm{x}}$ sensitive (Milford et al., 1994).

Figure 12 illustrates the $\mathrm{NO}_{\mathrm{x}}-\mathrm{VOC}$ sensitivity for the simulations (runs $\mathrm{N}$ and $\mathrm{V}$ ) in the bottom of the valley, every half an hour from 10:00 to 16:00 TU. Only meshes of the terrain with an altitude less than $1500 \mathrm{~m}$ above sea level are considered in order to include all the anthropogenic sources. 


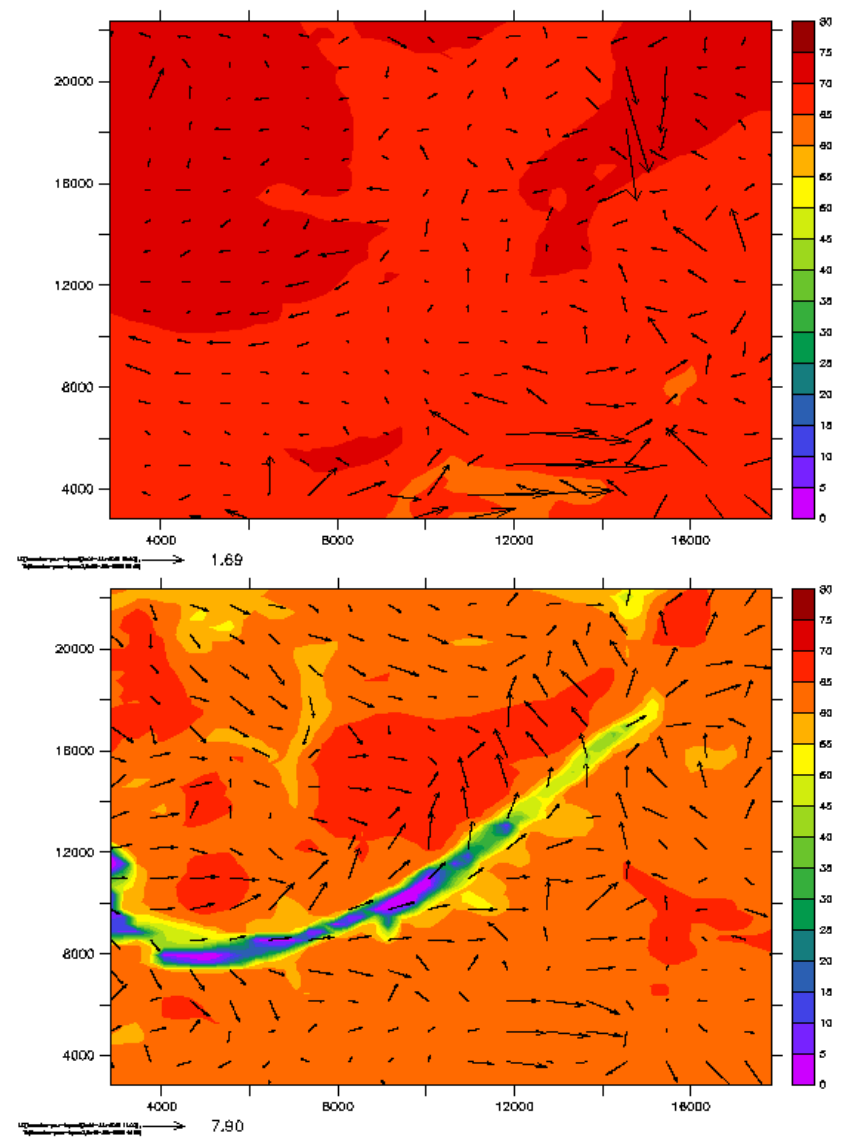

Fig. 11. Ozone concentration [ppb] and wind fields over Chamonix valley at 12:00 (top) and 21:00 (bottom); 10 July 2003.

Although a significant part of the domain area is rural-type, effects of non rural emission predominate.

The Fig. 12 shows the change in ozone concentrations associated with either reduced VOC (run V) or reduced $\mathrm{NO}_{\mathrm{x}}$ (run $\mathrm{N}$ ) relative to the domain. The positive values represent locations where, by decreasing the emission, a reduction in ozone is obtained while negative values result from locations where reduced emissions cause more ozone.

According to the results, the ozone production is VOC limited: only a diminution of VOC leads to a reduction of ozone concentration (run V).This conclusion differs from what was observed in the nearby city of Grenoble $(100 \mathrm{~km}$ from the valley in a $\mathrm{Y}$ shape convergence of three deep valleys) where a $\mathrm{NO}_{\mathrm{x}}$ controlled regime was observed (Couach et al., 2004). Measurements of ozone between 1998 and 2001 in the town of Chamonix agree with this result with a $5 \mathrm{ppb}$ increase of ozone concentration in summer. Nevertheless, this augmentation could be partly due to slight increase of regional concentration.
Table 5. Runs to determine ozone production regime. The reduction of $\mathrm{NO}_{\mathrm{x}}$ or VOC emissions is applied to both anthropogenic and biogenic sources.

\begin{tabular}{lccl}
\hline & Date & Duration & Emissions \\
\hline Run B & 7 July 2003 & $24 \mathrm{~h}$ & All \\
Run N & 7 July 2003 & $24 \mathrm{~h}$ & Run B $-50 \% \mathrm{NO}_{\mathrm{x}}$ \\
Run V & 7 July 2003 & $24 \mathrm{~h}$ & Run B -50\% VOC \\
\hline
\end{tabular}

\section{Conclusions}

A system of models has been built to model dispersion and evolution of pollutants in narrow valleys. The methodology is applied to Chamonix valley but similar results were obtained, still in the frame of the POVA program, in Maurienne valley which lies $80 \mathrm{~km}$ from Chamonix but with significantly different topography (lower summits, wider extension, west-east oriented) (Brulfert, 2004). This system is based on several atmosphere dynamics and gas chemistry numerical codes selected for their ability to deal with processes developing at different length and time scales. TAPOM and ARPS codes are used for fine space resolution when CHIMERE and MM5 are used at larger scales.

Three-dimensional photochemical simulations have been performed for a 7-day period with this system of models, during the POVA intensive period of observation in the topographically complex and narrow Chamonix valley. Results from the numerical simulation are in good agreement with observations. Wind direction and forces are well reproduced with wind reversal observed at the same times in the model and from measurements. The evolution of the mixed layer thickness induced by thermal convection is well represented with growth in the morning and decay at night. These features of atmosphere dynamics are of major importance for transport and dilution of pollutants. Discrepancies on temperature and time of the wind shift are often due to the difficulties in parameterizing humidity and soil temperature. The model well simulates clear sky conditions which are predominant in summer polluted events.

Computed concentrations are in good agreement with measured values, for both primary and secondary pollutants. Correlation between maximum of ozone and background values $(0.8)$ suggests the regional origin of the pollutant. Dilution of pollutants by wind transport (e.g. $\mathrm{NO}_{2}$ ) is weak: important concentrations are observed only close to the sources. In the upper valley, simulated and observed ozone concentrations agree less than for the other stations, especially at night where the model underestimates the values because of an overestimation of $\mathrm{NO}_{\mathrm{x}}$ in the emission inventory. Some discrepancies in measurements and model results may be attributed to the "proximity" character of the station with high emissions and measurements in the same mesh of the model. 


\section{NOy}

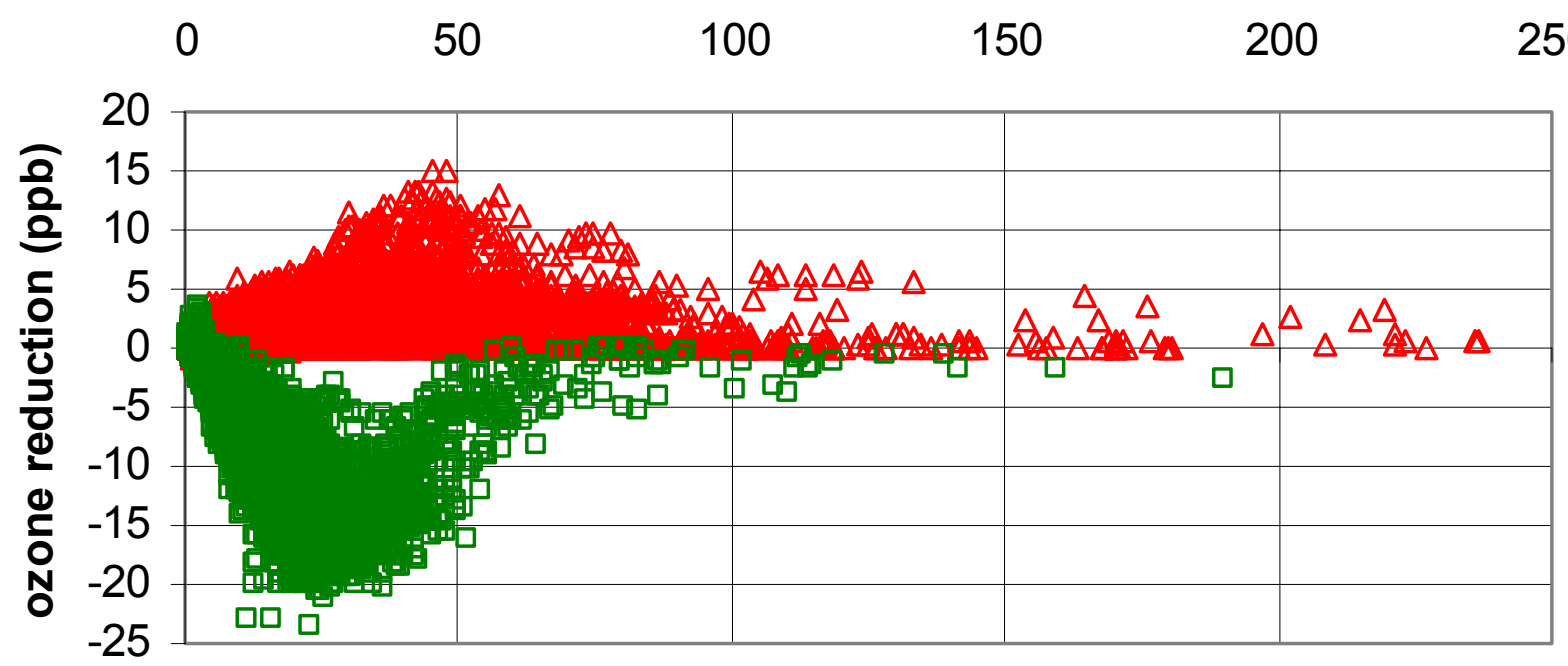

$\triangle$ VOC controls $\square$ NOx controls

Fig. 12. $\mathrm{NO}_{\mathrm{y}}$ according to ozone reduction with $\mathrm{NO}_{\mathrm{x}}$ and VOC decrease (from 10:00 to 16:00 TU).

For a later purpose of suggesting reduction strategy, the general trend of chemical process has to be characterized. Well chosen indicators based on some species concentrations allow to determine a prevailing mechanism. The $\mathrm{NO}_{\mathrm{y}}$ indicator shows that the region of the maximum ozone is VOC saturated.

With the transfer of traffic from Chamonix to Maurienne valley because of the accident of Mont-Blanc tunnel, program POVA investigates also Maurienne. As for Chamonix valley, primary and secondary pollution is considered with measurements and numerical simulations based on the very same system of models. Ozone production regime and indicators obtained in the two valleys will be compared.

Acknowledgements. The program POVA is supported by "Air de l'Ain et des Pays de Savoie", Région Rhône Alpes, ADEME, Primequal 2, METL, MEDD. Meteorological data are provided by Météo France and ECMWF, traffic data by STFTR, ATMB, DDE Savoie et Haute Savoie. Computations were done on Mirage. TAPOM comes from the Air and Soil Pollution Laboratory of the Ecole Polytechnique Fédérale de Lausanne.

Edited by: L. M. Frohn

\section{References}

Ambrosetti, P., Anfossi, D., Cieslik, S., Graziani, G., Lamprecht, R., Marzorati, A., Nodop, K., Sandroni, S., Stingele, A., and Zimmermann, H.: Mesoscale transport of atmospheric trace con- stituents across the central alps: TRANSALP tracer experiments, Atmos. Environ., 32(7), 1257-1272, 1998.

Anquetin, S., Guilbaud, C., and Chollet, J. P.: Thermal valley inversion impact on the dispersion of a passive polluant in a complex mountainous area, Atmos. Environ., 33, 3953-3959, 1999.

Brulfert, G., Chollet, J. P., Jouve, B., and Villard, H.: Atmospheric emission inventory of the Maurienne valley for an atmospheric numerical model, Sci. Total Environ., in press, 2005.

Brulfert, G.: Modélisation des circulations atmosphériques pour l'étude de la pollution des vallées alpines, Thesis manuscript, 263 pp., available on http://tel.ccsd.cnrs.fr/documents/archives0/ 00/00/79/82/index_fr.html, University Joseph Fourier, Grenoble, France, 2004.

Chaxel, E., Brulfert, G., Chemel, C., and Chollet, J. P.: Evaluation of local ozone production of Chamonix valley (France) during a regional smog episode. 27th NATO/CCMS International Technical Meeting on Air Pollution Modelling and its Application Banff, Canada, available on: http://www.dao.ua.pt/itm/27th/ Presentations, 25-29 October 2004.

Clappier, A.: A correction method for use in multidimensional time splitting advection algorithms: application to two and three dimensional transport, Mon. Wea. Rev., 126, 232-242, 1998.

Couach, O., Balin, I., Jiménez, R., Ristori, R., Kirchner, F., Perego, S., Simeonov, V., Calpini, B., and Van den Bergh, H: Investigation of the ozone and planetary boundary layer dynamics on the topographically-complex area of Grenoble by measurements and modeling, Atmos. Chem. Phys., 3, 549-562, 2003,

SRef-ID: 1680-7324/acp/2003-3-549.

Couach, O., Kirchner, F., Jimenez, R., Balin, I., Perego, S., and Van den Bergh, H.: A development of ozone abatement strategies 
fort he Grenoble area using modelling and indicators, Atmos. Environ., 38, 1425-1436, 2004.

Espace Mont Blanc: Technical report of the study Air Espace Mont Blanc, 147 pp., available at http://www.espace-mont-blanc.com, 2003.

Gong, W. and Cho, H.-R.: A numerical scheme for the integration of the gas phase chemical rate equations in a thre-dimensional atmospheric models, Atmos. Environ., 27A(14), 2147-2160, 1993.

Grell, G. A., Dudhia, J., and Stauffer, D. R.: A description of the Fifth-Generation Penn State/ NCAR Mesosale Model (MM5). NCAR technical note NCAR/TN-398+STR, NCAR, Boulder, CO. 117 pp., 1995.

Grell, G. A., Emeis, S., Stockwell, W. R., Schoenemeyer, T., Forkel, R., Michalakes, J., Knoche, R., and Seidl, W.: Application of a multiscale coupled MM5/chemistry model to the complex terrain of the VOTALP valley campaign, Atmos. Environ., 34(9), 14351453, 2000.

Jimenez, P., Baldasano, J. M, Dabdub, D.: Comparaison of photochemical mechanisms for air quality modeling, Atmos. Environ., 37, 4179-4194, 2003.

Lehning, M., Richner, H., and Kok, G. L.: Pollutant transport over complex terrain: flux and budget calculations fort he POLLUMET field campaign, Atmos. Environ., 30(17), 3027-3044, 1996.

Löffler-Mang, M., Zimmermann, H., and Fiedler, F.: Analysis of ground based operational network data acquired during the September 1992 TRACT campaign, Atmos. Environ., 32(7), 1229-1240, 1998.
Middleton, P., Stockwell, W. R., Carter, W. P. L.: Aggregation and analysis of volatile organic compound emissions for regional modeling, Atmos. Environ., 241(5), 1107-1133, 1990.

Milford, J. B. and Gao, D.: Total reactive nitrogen $\left(\mathrm{NO}_{\mathrm{y}}\right)$ as an indicator of the sensitivity of ozone to reductions in hydrocarbon and $\mathrm{NO}_{\mathrm{x}}$ emissions, J. Geophys. Res., 99(D2), 3533-3542, 1994.

Schmidt, H., Derognat, C., Vautard, R., and Beekmann, M.: A comparison of simulated and observed ozone mixing ratios for the summer of 1998 in Western Europe, Atmos. Environ., 35, 62776297, 2001.

Stockwell, R., Kirchner, F., Kuhn, M., and Seefeld, S.: A new mechanism for atmospheric chemistry modelling, J. Geophys. Res., 102(D22), 25 847-25 879, 1997.

Wotawa, G. and Kromp-Kolb, H.: The research project VOTALP - general objectives and main results, Atmos. Environ., 34(9), 1319-1322, 2000.

Xue, M., Droegemeir, V., and Wong, V.: The Advanced Regional Prediction System (ARPS)- A multi-scale nonhydrostatic atmospheric simulation and prediction model. Part I: Model dynamics and verification, Met. Atm. Phys., 75(3), 161-193, 2000.

Xue, M., Droegemeir, K. K., Wong, V., Shapiro, A., Brewster, K., Carr, F., Weber, D., Liu, Y., and Wang, D.: The advanced regional prediction system (arps) - a multi-scale non hydrostatic atmospheric simulation and prediction tool. Part ii: Model physics and applications, Met. Atm. Phys., 76, 143-165, 2001. 